\title{
Parents' Participation in Improving the Quality of Elementary School in the City of Malang, East Java, Indonesia
}

\author{
Raden Bambang Sumarsono ${ }^{1}$, Ali Imron ${ }^{1}$, Bambang Budi Wiyono ${ }^{1} \&$ Imron Arifin $^{1}$ \\ ${ }^{1}$ Educational Management Studies Program, Postgraduate State University of Malang, East Java, Indonesia \\ Correspondence: Raden Bambang Sumarsono, Department of Educational Administration, Facullty of Education, \\ State University of Malang, J1. Semarang 5 Malang, East Java 65145, Indonesia. E-mail: \\ raden.bambang.fip@um.ac.id
}

$\begin{array}{lc}\text { Received: April 5, 2016 } & \text { Accepted: May 12, } 2016 \quad \text { Online Published: September 28, } 2016 \\ \text { doi:10.5539/ies.v9n10p256 } & \text { URL: http://dx.doi.org/10.5539/ies.v9n10p256 }\end{array}$

\begin{abstract}
This research aims at describing parents participation in improving the quality of education of elementary schools viewed from the school substance and management. This is a qualitative research using phenomenology approach. The research design employed is comparative multicase involving four elementary schools in Malang city, East java, Indonesia. The choice on the researched schools are based on the recommendation from education office with regard to the school quality. The data collection is done by using in-depth interviews, observation, and document related to the parents participation in improving the quality of elementary school education. The analysis is conducted using flow model involving the stage of individual case analysis using flow model, which is then continued to cross cases data analysis which is done simultaneously. The result of data analysis found that parents participation in improving the quality of education of elementary schools is manifested in the aspects of learning, students affair, facilities and infrastructure, public relations, educational finance, and school personnel.
\end{abstract}

Keywords: parents' participation, improving the quality, elementary school

\section{Introduction}

The education system is a shared responsibility between government, parents, and community. Those three elements in accordance with their functions and roles should have great attempt to realize an optimal quality of education. A child will learn and grow in a family, school, and community environment. Family is the firrst and the most important environment for a child because family is seen as the foundation for child education children, and the primary responsibility of actual education rests in a family (Imron, 2013, p. 7).

At the level a family, the duty of parents ( it involves the role of a father and a mother) to educate their children in afamily life. Shochib (2010, p. 21) argues that the responsibility and trust of parents felt by the children will be the basis of imitation and identification to behave.

School environment with its typical structure and institutional system serves as a seedbed of the nation which has the obligation to educate and train its students. The school environment is created to help the educational process that has taken place within the family, while the surrounding communities with all its dynamics and characteristics will directly or indirectly influence the development of students as members of society.

This suggests the existence of a strong attachment between the government (schools), parents, and community. Kusmintardjo (2010, p. 195) states "the existence of a strong link between schools, families and communities which are actively involved in supporting the educational business and development of students, then will have a positive impact on education". Therefore, the shared responsibility between parents, communities, and schools in improving the quality of education should not be ignored.

According to Lezotte (1998), a quality school has several characteristics, namely (1) there is an effort to create a school culture; (2) there is a relationship between a quality and a school; (3) it is managed by implementing site-based management; (4) it always collects data and analyzes it; (5) it conducts a planning on school development; (6)it runs the school for students; (7) it establishes the relationship with the community; and (8) it evaluates students' progress. Meanwhile, Dagget (2005) provides some characteristics regarding a quality school, namely: (1) it has strong leadership; (2) it has good academic climate; (4) it has quiet and conducive school 
atmosphere ; (5) it constantly monitors students' progress. Those five characteristics are known as the five-factor models.

A quality school cannot be separated from the participation from students' parents. The participation or the involvement of parents in school is very important in creating a good quality school. According Brookover (Winoto, 2007), the involvement of students' parents at school is parents willingness to offer helps in solving problems at school. Those problems can be related to school related things such as learning, supervision, coordination, and other services at the school.

Gorton and Schneider (1991) suggest four things at once regarding the objectives of involving parents in school activities, namely: (1) to give better information about what students are learning in school, to give greater support to school renewal program, to give parents a broad understanding on the various problems faced by the school; (2) to encourage parents to provide school facilities to support children's learning activities at home including the development of students' personal and social skills; (3) to give parents chances in giving input of ideas, expertise, and human resources for school reform, and (4) to realize democratic and transparent school in the effort of realizing effective school management. The research result by Duke and Canady (1991) shows that the involvement of the school community including parents is very positive in supporting the successful implementation of a school policy.

Meanwhile, Gibbon (1986) reports the results of his research conducted at public schools in Columbus, Ohio which found that one of the factors that lead to school improvement is parents and community participation in school programs. Murillo (2002) also reports his research results regarding the effective school improvement in Spain and he found that parents involvement is very important to improve the quality of schooling. Thus it can be underlined that the parents participation in school will determine the success in achieving a quality school.

Previous researches conducted by some researchers also suggest that parents' participation is closely correlated to the success of children education or it positively affects students' learning progress (Preedy, 1993). Preedy's research results strengthen the results of research by Herman and Yeh (1993) stating that parents' participation is positively correlated with students' achievement and parents satisfaction to the school. While Sui-chu and Willm (1996) in their research reveal that parents involvement at home, especially in the case of accompanying their children in doing homework and planning the learning program will bring a strong impact on the school outcome.

Another research finding expressed by Murillo (2002) state that parents involvement is very important to improve the quality of education at school. Meanwhile, Kimaro and Machumu (2015) in their research state "the finding suggests that there was an existence of a positive and significant relationship between parents involvement in the school activities of their children and academic achievement". Castro et al. (2015) in their research reveal that, parents' involvement will bring the students into their academic achievement. The research finding reinforces the previous findings on the research conducted by Henderson and Berla (1994) stating that the interaction between children and parents at home to do school related things will give an impact on child's achievements and independence.

A number of researches which is previously described indicate that greater parents participation in the learning process will give a positive impact on children's success at school. Parents participation also supports child's academic achievement in higher education and also affects the child's emotional and social development.

Parents' participation in improving the quality of education is seen when they are involved in various activities at school. This research aims to reveal the parents participation in improving the quality of education at school seen from its aspects.

\section{Methods}

The researchers employed qualitative research since the form of the research data is in the form of descriptions and the data acquisition is inductive started from the conceptualization, categorization, and descriptions developed on the basis of events obtained through research in field. Bogdan and Biklen (2003) mention that a qualitative research will describe structured social life of the people. Meanwhile Mantja (2007, p. 33) states that qualitative research is a research procedure that produces descriptive data in the form of writings about the person or person's words and behavior that is real. In other words, a qualitative research brings researchers to know people personally and see them as they grow or live in accordance with their understanding of their own world. The approach used by the researchers in this research is phenomenological approach

The research design used by the researchers is a comparative multi case study. Comparative multi-case study design in this research refers to the idea of Bogdan and Biklen (2003) who stated "study two or more subjects, 
setting, or depositories of data they are usually doing what we call multi-case studies...others researchers do comparative case study...show generalizability or diversity". This comparative multi-case study design was done in two ways, namely (1) a single case study, which is a descriptive study in which each cases is used as the basis or the early foundation in comparing with other cases (the pilot for multi-case studies), and (2) multi-case study, which is a comparative study between cases (comparative case studies). There are four elementary schools used as research locations namely Kauman 1 Elementary School (case 1), Laboratorium Elementary School of State University of Malang (case 2), Islamic Elementary School of Malang 1 (case 3), and Khadijah Islamic Elementary School (case 4), in Malang city, East Java, Indonesia. Those two schools are public schools while the other two schools are private schools belonging to a private institution. Those four locations are regarded as schools which have the best reputation, performance, and achievement compared to other elementary schools in Malang East Java Indonesia.

The data collection techniques used by researchers are in-depth interviews, observation, and documentation. Meanwhile, to analyze the data obtained, the researchers use a technique by adopting flow model analysis of Miles and Huberman (1994), which includes the "three-step process analysis namely data reduction, data presentation and data verification or conclusion drawing. This analysis activity is conducted in an interactive form with the data collection process as a cycle". The data analysis is ongoing, recurrent and persistent. The flow model analysis includes the stages of analyzing individual case data, and it is continued into an analysis of cross case analysis. The real implementation of cross case data analysis done by the researchers are as follow: first, the finding of the data obtained from case 1 is arranged into categories and themes, which is then analyzed conceptually inductive, it is made into its narrative explanation, and it is arranged in a certain propositions and developed into a substantive theory 1 . Second, to analyze case 2,3 , and 4 , it is done in the same way as what is done in case 1. Third, at the final stage the simultaneous analysis is conducted to recommend and develop a conception of comparative cases 1,2,3, and 4 systematically. The final analysis is meant to draft the thematic side concept based on data analysis and narrative theoretical interpretation in the form of cross-case proposition which is then used as material for developing the findings or substantive theories in general.

\section{Results and Discussion}

The results obtained from the analysis of the research findings on parents participation in improving the quality of schools include the aspects of learning, student affairs, facilities and infrastructure, public relations, education finance, and education personnel. The details of the research findings on the aspects of parents participation in improving the quality of school will be described as follows.

\subsection{Learning Aspect}

Parents participation in improving the quality of schools in the learning aspect is manifested through parenting day activities as parents are actively involved to be a resource person, prepare field trip program, develop inspiring classroom, together with the teachers prepare the implementation of try out for students grade 6 , plan and evaluate the learning activities outside the classroom, and prepare the learning props that the learning process and the learning outcome will be more meaningful as the effort in improving the quality of education.

The findings are in line with the opinion of Ornstein and Levine (1985) who stated that parents can be involved in planning and solving problems in the areas of curriculum or learning programs or policies concerning student. Moreover, Bacharach (1990) described that parents involvement can help the students in preparing everything they need before, whilst, and after they attend a lesson at school. Parents, according to Reynolds, et al. (1996) may assist classroom teachers in explaining the particular subject matter according to their expertise or skills they have. The results of this research also support the findings by Riyani \& Mantja (2008) stating that parents have a role as substitute teachers and facility providers

\subsection{Students Affairs Aspect}

Parents participation in improving the quality of education in elementary schools in this aspect can be seen from the activities of developing students' interests and talents which is manifested into extracurricular programs, participating in the activity of celebration or commemoration for national holidays and religious, being involved in the activity of graduation ceremony of the sixth grader, participating in the activity of Pondok Ramadan, Gema Dzulhijah, and assisting the students when participating in competitions. The participation is done by parents either individually, or through community based organizations of parents and school committees. The participation takes place both incidentally and periodically or scheduled.

In this aspect, parents participation is manifested in the form of activities to plan, coordinate, implement until evaluate student activities. It supports the research of Ornstein and Levine (1986) stating that that parents can be 
involved in planning and solving problems in the areas of curriculum or learning programs or policies concerning student. Meanwhile Docking (1990) states that parents do not play a role as members of parents and teachers organization, but they also acts as persons who can set the policy on student behavior at school. Meanwhile, according to Bacharach (1990), parents can help preparing everything that their children need when following the art performance, exhibitions and the like.

The involvement or parents participation in education according to Olsen and Fuller (2003) will provide benefits to the students themselves, society, teachers, and schools. The benefits of parents involvement in the education for students are: (1) the students tend to benefit more regardless of race and background of economic status, or educational level of parents, (2) students generally attain the rank, grades, and attendance better, (3) students consistently complete their homework, (4) students become more disciplined and show a higher motivation to attend school, (5) the positive attitude of the students towards schools results in the improvement of students' attitudes at school so they rarely violate regulations, (6) there are fewer students who are placed in remidial classes, and (7) students who come from different cultures tend to do better if the parents and personnel educators work together to bridge the cultural differences that exist in the family and the school.

\subsection{Facilities and Infrastructure Aspect}

Parents participation of in the aspect of infrastructure is done by improving the infrastructure and facilities that support the implementation of the learning process. The participation of parents in this aspect include the development of school gardens, school buildings, construction of classrooms, provision of hand washing facilities, provision of learning aids, and construction of the school mosque.

Parents participation in this aspect has individual characteristics and it is well organized (through associations or committees). Individual in this case refers to the understanding that parents individually are active in providing infrastructure to support the elementary school. Meanwhile, in an organized way implies that parents give their participation through community or the school committee. Legally, according to the National Education Minister Decree No. 044 of 2002, the school committee is an organization empowering people and parents in improving the quality of education.

The finding of this research supports the opinion stated by Gorton and Schneider (1991), suggesting that there are four reasons on the importance of involving parents or the community in school activities, one of which is that parents provide supporting equipment to support children's learning activities. Likewise, according to Winoto (2007) it is said that the involvement of parents in school can be related to school related things for example in terms of improving school facilities and infrastructure.

\subsection{The Relationship Between School and Community Aspect}

Parents Participation in improving the quality of education in public relations aspect is realized by actively participate in the management committee, form and active in the community of parents, participate in the celebration of school anniversary, and school publications. Students Parents who are the members of school association or school committee help the elementary school by voluntarily supporting the implementation of school programs.

Students' parents community is a manifestation of the role of parents which is done in an organized way. This community is formed in order to strengthen the presence of the committee in its efforts to realize the quality school. Activities undertaken in this parents community aim at realizing the school program and thus it also has a cooperation with stakeholders. The coordinated things deal with both curricular and extracurricular activities. This is in accordance with the opinion of Gorton (1976), stating that parents have a role as members of school organisation and teachers, as well as members of the commission acting with a role in helping to solve the problem of school and help to make decisions and policies. Then these activities according to Aldridge and Goldman (2002), including activities involving the community as a member of the development team of school activities. Meanwhile Kowalski (2004) states that one of the categories in a partnership between the school and the community is the coordination, meaning that as a partner in the formal agreement to coordinate the various activities. Thus it can be said that, if the school committee and parents participate optimally, it will facilitate the success of the school in improving the quality expected.

\subsection{Financial Aspect}

Parents' Participation in improving the quality of education in the financial aspect is manifested into the activities of raising education funding, which includes the activity of funding the race, supporting the financing of field trips, making donations to support education and funding some selected extracurricular activities. Parents' participation in the financial aspect will indirectly assist schools in running the programs that has been 
developed by the school, so it can improve the quality of school achievement.

The elementary school as well as students' parents is an integral part of society. The presence of parents in school is a huge asset in contributing to realize the quality of education in schools. The right to live and survive depends very much on the parents of the school. And in this case the school really needs the help or parentparticipation in financial aspect for the survival of elementary school. Brookover (in Winoto, 2007) stated that the problems in school it can be related to things the organization of schools, for example in things related to finance

The finding on parents' participation on the financial aspects is in line with the opinion of Bacharach (1990) mentioning that parents can help preparing everything needed one of which is financial. Meanwhile, Zamroni (2000) sorts out public participation (parents' participation) toward a school into two; the first is related to the mobilization of funds, and the second is related to the attempt in improving the school quality. This is also consistent with a formal legal basis, as set forth in Law Number 20 Year 2003 on National Education System in Article 46, stating that the funding of education is a shared responsibility between government, local government, and society.

\subsection{School Personnel Aspect}

Parents' participation in improving the quality of schools in the aspect of school personnel is manifested in the form of training activities organized by the cooperation between schools and committees with the aim to improve the professionalism of teacher in the context of enhancing the school quality. One of the indicators showing that a school is qualified is when its school that is the teacher has high professional level. To realize it, parents show their participation by conducting a teacher training to develop competencies that support the achievement of the level of professionalism in teaching.

The professionalism of teachers will support the efforts in achieving students' academic and non-academic achievement and it really affects on the effort to improve the school quality. The result of this research is in line with a research conducted by Suryadi (2003) stating that school along with parents (in this case the school committe/madrasah) play a greater role in the planning, implementing and supervising the effort in improving the quality of education in schools. Meanwhile, (Aldridge \& Goldman, 2002) also say the same thing stating that the activity is a form of parents involvement as a member of the development team of school activities. This is obviously very relevant to the work of schools and parents who continually support and assist the learning and development of students, which will lead to the attainment of quality education in schools (Eceles \& Harold, 1993; Illinois State Board of Education, 1993).

\section{Conclusion}

Based on the research result, there are some conclutions made by the researchers as follow:

There are some aspects of parents participation in improving the quality of education in elementary schools: curriculum and learning, student affairs, facilities and infrastructure, public relations, finance, and education personnel.

1) Parents participation in improving the quality of schools in the learning aspect is manifested through parenting day activities as parents are actively involved to be a resource person, prepare field trip program, develop inspiring classroom, together with the teachers prepare the implementation of try out for students grade 6 , plan and evaluate the learning activities outside the classroom, and prepare the learning props that the learning process and the learning outcome will be more meaningful as the effort in improving the quality of education.

2) parents participation in improving the quality of education in elementary schools in this aspect can be seen from the activities of developing students' interests and talents which is manifested into extracurricular programs, participating in the activity of celebration or commemoration for national holidays and religious, being involved in the activity of graduation ceremony of the sixth grader, participating in the activity of Pondok Ramadan, gema Dzulhijah, and assisting the students when participating in competitions. The participation is done by parents either individually, or through community based organizations of parents and school committees.

3) Parents participation of in the aspect of infrastructure is done by improving the infrastructure and facilities that support the implementation of the learning process. The participation of parents in this aspect include the development of school gardens, school buildings, construction of classrooms, provision of hand washing facilities, provision of learning aids, and construction of the school mosque.

4) Parents Participation in improving the quality of education in public relations aspect is realized by actively participate in the management committee, form and active in the community of parents, participate in the 
celebration of school anniversary, and school publications. Students Parents who are the members of school association or school committee help the elementary school by voluntarily supporting the implementation of school programs.

5) Parents Participation in improving the quality of education in the financial aspect is manifested into the activities of raising education funding, which includes the activity of funding the race, supporting the financing of field trips, making donations to support education and funding some selected extracuricular activities.

6) Parents Participation in improving the quality of education in the aspect of educational personnel is manifested in the forms of training activities organized by the cooperation between schools and committees with the aim to improve the professionalism of teachers in learning that supports the efforts to improve school quality.

\section{Acknowledgments}

The researchers thank the Director of Research and Community Services, Directorate General for Strengthening Research and Development, Ministry of Research, Technology and Higher Education, which has provided a research grant for doctoral dissertation. Next, a big thank is also addressed to Burhanudin, PhD, Lecturer at Department of Educational Administration, Facullty of Education, State University of Malang, who has provided helpful discussion and help in the preparation of the article.

\section{References}

Aldridge, J., \& Goldman, R. (2002). Current Issues and Trends in Education. Boston: Allyn and Bacon.

Bacharach. S. B. (1990). Education Reform: Making Sense of It All. Boston: Allyn and Bacon.

Bogdan, R. C., \& Biklen, S. K. (2003). Qualitatif Research for Education (An Introduction to Theories and Methods) (4th ed.). Boston: Allyn \& bacon, Inc.

Castro, M., Casas, E., Martin, E., Lizasoain, L., Asencio, E., \& Gaviria, J. (2015). Parental Involvement on Student Academic Achievement: A Meta-Analysis. Education Research Review, 14, 33-46. http://dx.doi.org/10.1016/j.edurev.2015.01.002

Dagett, W. R. (2005). Successful School: From Research to Action Plan. Retrieved from http://www.quality.cr.k12.ia.us/Resources/SuccessfulSchools_Daggett_05.pdf

Depertemen Pendidikan Nasional. (2007). Pendidikan dan Pelatihan: Manajemen Hubungan Masyarakat dalam Pemberdayaan Masyarakat. Jakarta: Ditnaga Ditjen PMPTK.

Docking, J. (1990). Primary Schools and Parents: Rights, Responsibility, and Relationship. London: Hodder \& Stronghton.

Duke, L. D., \& Canady, R. L. (1991). School Policy. New York: McGraw Hill Inc.

Eccles, J. S., \& Harold, R. D. (1993). Parent-School Involvement during the Early Adolescent Years. Teacher college Record, 94(3), 568-587.

Gibbons, M. (1986). School Improvement Program. Ohio: Culumbus Public School, Dept. of Evalution Service.

Gorton, R. A., \& Schneider, G. T. (1991). School-Based Leadership: Challenges and Opportunities. Dubuque: Wim. C. Brown Company Publisher.

Gorton, R. A. (1976). School Administration (Chalangge and Opportunity for Leadership). Iowa: Wim. C. Brown Company Publisher.

Hendersen, A. T., \& Berla, N. (1994). A New Generation of Evidence: The Family is Critical to Student Achievement. Washington, DC: National Commitee For Citizen in Education.

Herman, J. L., \& Yeh, J. P. (1983). Some Effective of Parent Involvement in School. Urban Review, 15(1), 11-16. http://dx.doi.org/10.1007/BF01112339

Illionis State Board of Education. (1993). The Relation Between Parent Involvement and Student Achievement: A Review of The Literature (ERIC Document Reproduction Service No. ED 357-848). Springfield, IL: Department of Planning Research and Evaluation.

Imron, A. (2013). Relationship Management and Public Participation. Teaching materials. Malang: Department of Education Administration, Faculty of Education, State University of Malang.

James, C. F., \& Peter, P. (1998). The Practice of Educational Marketing in School. Educational Management Strategy, Quality, and Resources. Ed. Philadelphia: Open University Press.

Kimaro, A. R., \& Machumu, H. J. (2015). Impacts of Parental Involvement in School Activities on Academic 
Achievement of Primary School Children. International Journal of Education and Research, 3(8).

Kowalski, T. J. (2004). Public Relations in School. Upper Saddle River, New Jersey: Merrill/Prentice Hall.

Kusmintardjo. (2010). Manajemen Keterlibatan Orang Tua dalam Pendidikan. Manajemen Pendidikan, 23(2), 195-203.

Lezotte, L. W. (1988). Revolutionary and Evaluationary: The Effective Schools Movent. Retrieved from https://www.edutopia.org/edutopia.org-closing-achievement-RevEv.pdf

Mantja, W. (2007). Etnografi: Desain Penelitian Kualitatif Pendidikan dan Manajemen Pendidikan. Malang: Elang Mas.

Milles, M. B., \& Huberman, M. A. (1994). Data Management and Analysis Methods. Handbook of qualitative Research. Thousand Oaks, CA: Sage.

Murillo, I. I. (2002). Good Effective School Improvement in Spain. Educational Research and Evaluation, 8(4), 387-410. http://dx.doi.org/10.1076/edre.8.4.387.8817

Olsen, G., \& Fuller, M. L. (2003). Home-School Relations: Working Successfully with Parent and Families (2nd ed.). Boston: Allyn and Bacon.

Orrstein, A. C., \& Levine, D. U. (1985). An Inttroducting to the Foundations of Education. Boston: Houghton Mifflin Company.

Preedy, M. (Ed). (1993). Managing the Effective School. London: The Open University.

Reynolds, D., Bollen, R., Creemers, B., Hopkins, D., Stoll, L., \& Lagerwejj, N. (1996). Making Good Schools: Linking Schools Effectiveness and School Improvement. London: Routledge.

Riyani \& Mantja, W. (2008). Peran Orang Tua dalam Membantu Pembelajaran Anak di Rumah. Jurnal Ilmu Pendidikan, 21(1), 13-26.

Shochib, M. (2010). Pola Asuh Orang Tua dalam Membantu Anak Mengembangkan Disipliln Diri. Jakarta: Rineka Cipta.

Sui-Chu, E. H., \& Willms, J. D. (1996). Effects of Parental Involvement on Eighth-Grade Achievement. Sociology of Education, 69(2), 126-141.

Suryadi, A. (2003). Dewan Pendidikan dan Komite Sekolah Mewujudkan Sekolah-Sekolah yang Mandiri dan Otonom. Retrieved from http://www.depdiknas.go.id.serba-serbidpks/pemberdayaandpks/html

Winoto, S. (2007). Komite Sekolah dalam Proses Manajemen Peningkatan Mutu Pendidikan (Studi Multikasus di SMP Nusa bangsa Malang dan MTs Harapan Bangsa Malang). Disertasi tidak diterbitkan. Malang: Program Pascasarjana Universitas Negeri Malang.

Zamroni. (2000). Paradigma Pendidikan Masa Depan. Yogyakarta: Biptaf Publishing.

\section{Copyrights}

Copyright for this article is retained by the author(s), with first publication rights granted to the journal.

This is an open-access article distributed under the terms and conditions of the Creative Commons Attribution license (http://creativecommons.org/licenses/by/4.0/). 